\title{
Rendimiento de papa con fuentes de fertilización mineral en un Andosol del Estado de México*
}

\section{Potato yield with mineral fertilizer on Andosol soils in the State of Mexico}

\author{
José Luis Morales Hernández ${ }^{1}$, Juvencio Hernández Martínez ${ }^{1}$ y Samuel Rebollar Rebollar ${ }^{1}$ \\ ${ }^{1}$ Centro Universitario UAEM-Temascaltepec.Carretera Toluca/Tejupilco,km 67.5.Tely fax (01726) 2665209.(jh_martinez1214@yahoo.com.mx; srebollarr@uaemex. \\ mx). ${ }^{\S}$ Autor para correspondencia: joselui2001@hotmailcom.
}

\section{Resumen}

El experimento se realizó en un suelo Andosol en la comunidad de la Peñuela del municipio de Zinacantepec, Estado de México en 2009, con los objetivos de: a) evaluar el rendimiento de tubérculo de papa (Solanum tuberosum L.) cultivar Fianna, en respuesta a niveles de nitrógeno, fósforo y potasio, con fuentes comerciales de fertilizante; $y b$ ) estimar óptimos económicos de capital limitado e ilimitado. Los niveles de nutrientes que se sometieron a evaluación fueron: $150,200,250,300,350 \mathrm{~kg} \mathrm{ha}^{-1} \mathrm{de} \mathrm{N} ; 00,200,250,300,350$,

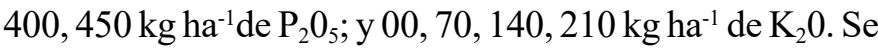
diseñaron 18 tratamientos, los cuales se evaluaron en un diseño experimental de bloques al azar, con cuatro repeticiones, se verificaron las repuestas a $\mathrm{N}, \mathrm{P}_{2} \mathrm{O}_{5}$ y $\mathrm{K}_{2} \mathrm{O}$ con el método gráfico de Turrent. Los resultados indican mejor capacidad de rendimiento en los tratamientos cuatro $\left(34.3\right.$ tha $^{-1}, 300-350-70$ $\left.\mathrm{kg} \mathrm{ha}^{-1} \mathrm{~N}, \mathrm{P}_{2} \mathrm{O}_{5}, \mathrm{~K}_{2} \mathrm{O}\right)$ y siete $\left(33.7 \mathrm{tha}^{-1}: 150-250-70 \mathrm{~kg} \mathrm{ha}^{-1}\right.$ $\mathrm{N}, \mathrm{P}_{2} \mathrm{O}_{5}, \mathrm{~K}_{2} \mathrm{O}$ ), ambos diferentes estadísticamente del resto de tratamientos $(\alpha<0.05)$, con un coeficiente de variación $25.9 \%$. El óptimo económico de capital ilimitado se ubicó en el tratamiento cuatro (300-350-70 $\mathrm{kg} \mathrm{ha}^{-1} \mathrm{de} \mathrm{N}, \mathrm{P}_{2} \mathrm{O}_{5}$ y K $\mathrm{K}_{2} \mathrm{O}$ ), con un mayor ingreso neto. Elóptimo económico, para capital limitado, se localizó en el tratamiento siete. Se concluye que existe respuesta en rendimiento relacionado con dosisóptimas por el uso de difosfato de amonio, fosfonitrato y cloruro de potasio en la región de estudio.

\section{Abstract}

The experiment was conducted in an Andosol soil in the community of Peñuela, municipality of Zinacantepec, State of Mexico in 2009, with the objectives: a) evaluate the yield of potato tubers (Solanum tuberosum L.) cultivar Fianna, in response of nitrogen, phosphorus and potassium levels, with commercial fertilizer and b) estimate optimum economic levels for limited and unlimited capital. Nutrient levels subjected for evaluation were: 150, 200, 250, 300, $350 \mathrm{~kg} \mathrm{ha}^{-1}$ of N, 00, 200, 250,300,350,400, $450 \mathrm{~kg} \mathrm{ha}^{-1}$ of $\mathrm{P}_{2} 0_{5}$, and $00,70,140,210 \mathrm{~kg} \mathrm{ha}^{-1}$ of $\mathrm{K}_{2} 0.18$ treatments were designed, which were evaluated in an experimental design of randomized blocks, with four replications; responses to $\mathrm{N}, \mathrm{P}_{2} \mathrm{O}_{5}$ and $\mathrm{K}_{2} \mathrm{O}$ were verified with the Turrent graphical method. The results indicate better yield capability in treatments four $\left(34.3 \mathrm{tha}^{-1}, 300-350-70 \mathrm{~kg} \mathrm{ha}^{-1} \mathrm{~N}, \mathrm{P}_{2} \mathrm{O}_{5}, \mathrm{~K}_{2} \mathrm{O}\right)$ and seven (33.7 $\mathrm{t} \mathrm{ha}^{-1}: 150-250-70 \mathrm{~kg} \mathrm{ha}^{-1} \mathrm{~N}, \mathrm{P}_{2} \mathrm{O}_{5}, \mathrm{~K}_{2} \mathrm{O}$ ), both statistically different from the other treatments $(\alpha<$ 0.05 ), with a variation coefficient of $25.9 \%$. The optimum economic of unlimited capital was located in treatment four (300-350-70 kg ha-1 of N, $\mathrm{P}_{2} \mathrm{O}_{5}$ and $\mathrm{K}_{2} \mathrm{O}$ ), with a higher net income. The optimum economic for limited capital, was located in treatment seven. It is conclude that there is a yield response associated with optimal doses by the use of ammonium diphosphate, phosphonitrate and potassium chloride in the study region.

\footnotetext{
* Recibido: octubre de 2012

Aceptado: junio de 2013
} 
Palabras clave: Andosol, óptimo económico, capital ilimitado, fertilización con N, P, y K.

\section{Introducción}

La fertilización del cultivo de la papa es una práctica fundamental en los valles altos de México, ya que, permite mantener e incrementar de manera importante el rendimiento y la calidad de los tubérculos en las variedades utilizadas. La fertilización generalmente representa alrededor de $20 \%$ de los costos totales de producción.

En el municipio de Zinacantepec, en el Estado de México, el cultivo de la papa se siembra en aproximadamente 1600 ha, con un rendimiento promedio de 18 tha $^{-1}$. Ésta productividad se puede incrementar con el uso de variedades mejoradas y con prácticas que optimicen la aplicación de nitrógeno, fósforo y potasio, ya que el productor utiliza dosis de fertilización no equilibradas en estos nutrientes.

Así, los efectos de la fertilización en la productividad, se pueden evaluar, estudiar y optimizar con diferentes metodologías; De acuerdo con Sifuentes et al. (2009) la necesidad de fertilizar al cultivo de la papa se basa en el estudio de los requerimientos nutrimentales que permitan estimar las dosis requeridas por el cultivo. Una metodología muy utilizada en México Turrent (1981), Cochram y Cox (2004) permite interpretar las respuestas de fertilizantes y otros factores de manera flexible, en forma matemática y de manera gráfica. De manera complementaria el método discreto Volke (1982), permite evaluar óptimos económicos de capital limitado e ilimitado.

Por otra parte, los suelos de la región central del Estado de México son derivados de cenizas volcánicas, los cuales se caracterizan por su capacidad de reaccionar rápidamente con grandes cantidades de fósforo, en particular en condiciones ácidas Egawa (1980) y en consecuencia, la disponibilidad del fósforo de los fertilizantes fosfatados solubles para las plantas es fuertemente reducida, llegando a sólo alrededor de $10 \%$ del P aplicado al suelo, por lo que la papa obtiene una respuesta positiva a la aplicación de fósforo Bertsch (2003) en este tipo se suelos (Holford, 1977).

En el caso de la papa el coeficiente de eficiencia de los fertilizantes nitrogenados Hong Li et al. (2006) es 65\%. De los fosforados Syers (2008) es de 50 a 90\% y de los potásicos
Key words: Andosol, optimum economic, unlimited capital, fertilization with $\mathrm{N}, \mathrm{P}$, and $\mathrm{K}$.

\section{Introduction}

The fertilization of potato crop is a fundamental practice in the high valleys of Mexico, since it allows maintaining and increasing significantly the yield and quality of tubers in the varieties. Fertilization usually represents about $20 \%$ of total production costs.

In the municipality of Zinacantepec, State of Mexico, the potato crop is planted in about 1600 ha with an average yield of $18 \mathrm{tha}^{-1}$. This productivity can be increased with the use of improved varieties and practices to optimize the application of nitrogen, phosphorus and potassium, since the producer uses unbalanced doses of fertilization of these nutrients.

Thus, fertilization effects on productivity can be evaluated, study and optimized with different methodologies; According to Sifuentes et al. (2009) the need to fertilize the potato crop is based on the study of the nutritional requirements to estimate the doses required by the crop. A methodology widely used in Mexico Turrent (1981), Cochran and Cox (2004) allows to interpret the responses of fertilizers and other factors in a flexible, mathematically and graphically manner. In a complementary manner the discreet method Volke (1982) allows to evaluate optimum economic for limited and unlimited capital.

Furthermore, soils in the central region of the State of Mexico are derived from volcanic ash, which are characterized by their capacity to react quickly with large amounts of phosphorus, in particular under acidic conditions Egawa (1980) and consequently the availability of phosphorus from soluble phosphate fertilizers for plants is greatly reduced, reaching only about $10 \%$ of $\mathrm{P}$ applied to the soil, so potato gets a positive response to the application of phosphorus Bertsch (2003) in this type soils (Holford, 1977).

In the case of potatoes the coefficient of efficiency of nitrogen fertilizers Hong Li et al. (2006) is $65 \%$. Of phosphate Syers (2008) is 50 to $90 \%$ and the potassium is in function of limestone and clay content Oltra et al. (2002), these elements, give importance to the determination of optimal doses of nitrogen and phosphate fertilization. 
es función de caliza y del contenido de arcilla Oltra et al. (2002), estos elementos, dan en consecuencia importancia a la determinación de dosis optimas de fertilización nitrogenada y fosfórica.

En este contexto, es importante determinar el nivel de utilización de los fertilizantes aplicados en esta hortaliza en un sueloAndosol, por lo que seplantearon los objetivos siguientes: determinar la respuesta agronómica en rendimiento que presenta el cultivo de papa a diferentes niveles de nitrógeno, fósforo y potasio con diferentes fuentes comerciales de fertilizante; y determinar el tratamiento óptimo económico de capital limitado e ilimitado para riego, en el municipio de Zinacantepec, Estado de México. La hipótesis es que existirá una respuesta mayor en rendimiento de tubérculo por la aplicación de nitrógeno y fósforo en suelos Andosoles y que esta se asociará con los niveles óptimos económicos.

\section{Materiales y métodos}

La Peñuela se ubica en las faldas del volcán Xinantécatl, en su ladera sur-poniente, pertenece al municipio de Zinacantepec, Estado de México Franco, et al. (2004). Esta localidad presenta las coordenadas geográficas $19^{\circ} 08^{\prime} 54.93$ " latitud norte y $99^{\circ} 49^{\prime} 08.88^{\prime \prime}$ longitud oeste, con altitud de 2890 m. El municipio, según la clasificación climática de Köppen modificada por García (1981), presenta clima templado subhúmedo, temperatura en el verano de hasta $28^{\circ} \mathrm{C}$ y en invierno hasta $-5^{\circ} \mathrm{C}$.

Las características de las variables edáficas son: suelo franco arenoso, densidad g/ $\mathrm{cm}^{3} 0-30 \mathrm{~cm}$ con 0.94 y $30-60 \mathrm{~cm}$ con $0.79, \mathrm{pH}(0-30) 5.74$ y $(30-60 \mathrm{~cm}) 5.97$, materia orgánica 5.04 a 5.54 , nitrógeno 0.21 a $0.23 \%$, fósforo en ppm 3.09 a 3.25 (bajo), potasio en ppm 13.12 a 14.28 bajo, calcio ppm 11.52 bajo, magnesio ppm 100 a 105 medio(UAEM, 2009).

\section{Diseño de tratamientos y diseño experimental}

Se condujo un experimento de marzo a agosto de 2009, bajo condiciones de riego, en La Peñuela, municipio de Zinacantepec, Estado de México en suelo Andosol, los factores controlables estudiados de la producción fueron: a) la variedad Fianna y b) los niveles de nutrientes: 150, $200,250,300,350 \mathrm{~kg} \mathrm{ha}^{-1} \mathrm{~N} ; 00,200,250,300,350,400$, $450 \mathrm{~kg} \mathrm{ha}^{-1} \mathrm{P}_{2} 0_{5}$; y 00, 70, 140, $210 \mathrm{~kg} \mathrm{ha}^{-1} \mathrm{de} \mathrm{K}_{2} 0$ en base a productos comerciales de fertilizante.
In this context it is important to determine the level of use of fertilizer applied in this vegetable in Andosol soil, so the following objectives were raised: determine the agronomic response in the actual yield of potato crop at different levels of nitrogen, phosphorus and potassium with different commercial fertilizer; and determine the optimum economic treatment for limited and unlimited capital for irrigation, in the municipality of Zinacantepec, State of Mexico. The hypothesis is that there will be a higher response in tuber yield by the application of nitrogen and phosphorus in Andosol soils and that this will be associated with optimum economic levels.

\section{Materials and methods}

The Peñuela is located on the slopes of the volcano Xinantecatl, in its south-west side, belongs to the municipality ofZinacantepec, State of Mexico Franco, et al. (2004). This locality has the geographical coordinates $19{ }^{\circ} 08$ '54.93" North and $99^{\circ} 49^{\prime} 08.88^{\prime \prime}$ West with altitude of $2890 \mathrm{~m}$. The municipality, according to the Koppen climate classification modified by García (1981), presents a humid temperate climate, summer temperatures up to $28^{\circ} \mathrm{C}$ and in winter to $-5^{\circ} \mathrm{C}$.

The characteristics of the soil variables are: sandy loam, density $\mathrm{g} / \mathrm{cm}^{3} 0-30 \mathrm{~cm}$ with 0.94 and $30-60 \mathrm{~cm}$ with 0.79 , $\mathrm{pH}(0-30) 5.74$ and $(30-60 \mathrm{~cm}) 5.97$, organic matter 5.04 to 5.54 , nitrogen 0.21 to $0.23 \%$, phosphorus in ppm 3.09 to 3.25 (low), potassium in ppm 13.12 to 14.28 (low), calcium in ppm 11.52 (low), magnesium ppm 100-105 (medium) (UAEM, 2009).

\section{Design of treatments and experimental design}

An experiment was conducted from March to August 2009, under irrigated conditions in the Peñuela municipality of Zinacantepec, State of Mexico in Andosol soil; the studied controllable factors of production were: a) the Fianna variety b) nutrients levels: $150,200,250,300,350 \mathrm{~kg} \mathrm{ha}^{-1} \mathrm{~N}, 00$, $200,250,300,350,400,450 \mathrm{~kg} \mathrm{ha}^{-1} \mathrm{P}_{2} 0_{5}$, and 00, 70, 140, $210 \mathrm{~kg} \mathrm{ha}^{-1} \mathrm{~K}_{2} 0$ based on commercial fertilizers.

The experimental design was a randomized block with four replications, the first four treatments were generated with factorial design methodology $2^{2}$ Cochran and Cox (2004), the following six treatments (T5-T10) were controls for P, K, 
El diseño experimental fue un bloque al azar, con cuatro repeticiones, los primeros cuatro tratamientos se generaron con la metodología de diseños factoriales $2^{2}$ Cochram y Cox (2004), los siguientes seis tratamientos (T5-T10) fueron testigos para $\mathrm{P}, \mathrm{K}$, los ocho tratamientos siguientes, 11 a 18 , se basan en extensiones del factorial $2^{2}$, se aplicaron fuentes comerciales de fertilizante, mismas que se distribuyeron de la siguiente manera:

Tratamientos fuentes comerciales.

1-10 Difosfato de amonio (18-46-00\% NPK); $15-18\}$ fosfonitrato $(33 \% \mathrm{~N})$ y cloruro de potasio $(60 \% \mathrm{~K}$. 11 Urea (46\%), superfosfato de calcio triple $(46 \% \mathrm{P})$, cloruro de potasio $\left(60 \% \mathrm{~K}_{2} 0\right)$.

12 Urea (46\%), superfosfato de calcio simple (20.5 P), cloruro de potasio.

13 Triple 16-16-16.

14 Sulfato de amonio (20.5\% N), superfosfato de calcio simple $(20.5 \% \mathrm{P})$, cloruro potasio.

La variedad Fianna, es de reciente introducción en el municipio de Zinacantepec, por el Instituto Nacional de Investigaciones Forestales, Agrícolas y Pecuarias (INIFAP), de ciclo intermedio (120 a 125 días) de cutícula blanca, resistente al tizón tardío.

La orientación del diseño experimental se ubicó de oriente a poniente. El tamaño de la parcela experimental consistió de tres surcos de $5 \mathrm{~m}$ de largo y $0.90 \mathrm{~m}$ de ancho entre surcos $\left(13.5 \mathrm{~m}^{2}\right)$; la parcela experimental útil consideró el surco central $\left(4.5 \mathrm{~m}^{2}\right)$. La distancia entre plantas aplicada fue de 0.2 m entre planta para un total de 55000 plantas por hectárea.

\section{Desarrollo experimental}

Riegos. Se aplicó un riego de presiembra, durante el mes de febrero. Después de la siembra, se dio un riego de auxilio para la germinación de la planta y 20 días después nuevamente se rego en la fase vegetativa de crecimiento de la planta, posteriormente se cerró el ciclo del cultivo en su fase de formación de tubérculo con agua del temporal.

La preparación del terreno se realizó en el mes de febrero de 2009, la semilla, se trató con Captan, en dosis de $1 \mathrm{~g}$ L. Previo al depositó de la semilla-tubérculo se efectuó la aplicación de los 18 tratamientos de fertilización. La siembra se efectuó el 1 de marzo de 2009, la primera escarda se realizó a los 17 días de la emergencia. the following eight treatments, 11 to 18 , based on factorial extensions $2^{2}$; were applied commercial sources of fertilizer, which were distributed in the following manner:

Treatments commercial sources.

1-10 Ammonium diphosphate (NPK 18-46-00\%); $15-18$ phosphonitrate $(33 \% \mathrm{~N})$ and potassium chloride $(60 \% \mathrm{~K}$.

11 Urea (46\%), calcium triple superphosphate $(46 \% \mathrm{P})$, potassium chloride $\left(60 \% \mathrm{~K}_{2} 0\right)$.

12 Urea (46\%), simple calcium superphosphate (20.5 $\mathrm{P})$, potassium chloride.

13 Triple 16-16-16.

14 Ammonium sulfate $(20.5 \% \mathrm{~N})$, single calcium superphosphate $(20.5 \% \mathrm{P})$, potassium chloride.

The variety Fianna, is newly introduced in the municipality of Zinacantepec, by the National Institute for Forestry, Agriculture and Livestock (INIFAP), intermediate cycle (120-125 days) of white cuticle, resistant to late blight.

The experimental design orientation was located from east to west. The size of the experimental plot consisted of three rows, $5 \mathrm{~m}$ long and $0.90 \mathrm{~m}$ width between rows $\left(13.5 \mathrm{~m}^{2}\right)$; the useful experimental plot considered the central rows $(4.5$ $\mathrm{m}^{2}$ ). The distance between plants was $0.2 \mathrm{~m}$ for a total of 55 000 plants per hectare.

\section{Experimental development}

Irrigation. Was applied a preplant irrigation, during the month of February. After planting, was applied a supplemental irrigation for germination and again 20 days after, in the vegetative stage, subsequently in the tuber formation, irrigation was rainfed.

Land preparation was done in February 2009 the seeds were treated with Captan, in doses of $1 \mathrm{gL}$. Previous to planting the seed-tuber was applied the 18 fertilizer treatments. Planting took place on March 1, 2009; the first weeding was done at 17 days after emergence.

Two preventive applications of methyl parathion were applied against the attack of paratrioza (Bactericera cockerelli), at $2 \mathrm{~L}$ ha in $200 \mathrm{~L}$ of water. For preventive and corrective control on late blight (Phytophthora infestans (Mont) de Bary) was used ridomil bravo ph and mancozeb 
Se realizaron dos aplicaciones preventivas de parathión metílico contra el ataque de paratrioza (Bactericera cockerelli), a razón de 2 L ha en 200 L de agua. Para el control preventivo y correctivo de tizón tardio (Phytophthora infestans (Mont) de Bary) se utilizó ridomil bravo ph y mancozeb en dosis de $1 \mathrm{~kg} \mathrm{ha}^{-1}$ en $200 \mathrm{~L}$ de agua. El corte de follaje se realizó con hoz, el 27 de julio. La cosecha fue a los 150 días de la siembra efectuándose esta, el 08 de agosto, en la cual se registró el rendimiento de tubérculo por categoría.

\section{Variables de estudio, análisis estadístico y económico}

Los datos registrados en la parcela experimental útil fueron: rendimiento de tubérculo primera (RP), segunda (RS), tercera categoría (RTE), y rendimiento total de tubérculo (RT), expresados en kilogramo por parcela y transformados a t ha ${ }^{-1}$. Las categorías se basan en datos de la Secretaría de Economía. (SE, 2002).

Para cada variable registrada se realizó un análisis de varianza y comparación de medias de tratamientos, con la prueba de Tukey, en un nivel de significancia de 5\%. Con los rendimientos obtenidos y aplicando el método gráfico de la matriz experimental Plan Puebla, se obtiene la respuesta gráfica de rendimiento en los tratamientos. Se determinaron los ingresos netos con el método discreto para obtener los óptimos económicos de capital limitado e ilimitado (Volke, 1982).

\section{Resultados y discusión}

El análisis de varianza para rendimiento total de tubérculo y las otras categorías de papa se presenta en el Cuadro 1, e indica que hubo resultados estadísticamente significativos $(p<0.01 \%)$ para el rendimiento total de tubérculo (RT) y el rendimiento de segunda categoría (RS), mientras que en la primera categoría (RP) fueron significativos $(p<$ $0.05 \%)$. Los coeficientes de variación para rendimiento total de tubérculo, primera y segunda categoría se pueden considerar normales. La significancia obtenida en éste experimento, por la adición de nitrógeno y de fósforo, era de esperar, debido a que la interacción nitrógeno-fósforo es común en el cultivo de la papa (Berrios, 2010). in doses of $1 \mathrm{~kg} \mathrm{ha}^{-1}$ in $200 \mathrm{~L}$ of water. The foliage was cut with a sickle, on July 27. The harvest was at 150 days after planting, on August 08, yield was recorded by category.

\section{Study variables, statistical and economic analysis}

The data recorded in the experimental plot were useful: first tuber yield (RP), second (RS), third category (RTE) and total tuber yield (RT), expressed in kilograms per plot and converted to $\mathrm{tha}^{-1}$. The categories are based on data from the Ministry of Economy (SE, 2002).

For each variable recorded was made an analysis of variance and comparison of means from the treatment with Tukey's test at a significance level of 5\%. With the recorded yields and applying the graphical method of experimental matrix Plan Puebla, is obtained a graphical response of yield in the treatments. Net incomes were determined with the discrete method to obtain the optimum economics for a limited and unlimited capital (Volke, 1982).

\section{Results and discussion}

The analysis of variance for total tuber yield and other categories of potato is presented in Table 1 , indicating that there were statistically significant results $(p<0.01 \%)$ for total yield of tubers (RT) and the yield of second category (RS), while in the first category (RP) were significant $(p<0.05 \%)$. The coefficients of variation for total yield of tuber, on the first and second category can be considered normal. Significance obtained in this experiment by the addition of nitrogen and phosphorus, was expected, because the nitrogen-phosphorus interaction is common in potato cultivation (Berrios, 2010).

Yield response of 34 and $33 \mathrm{tha}^{-1}$ in two treatments (four and seven) for this experiment, were lower than those obtained by a Rueda (1991) in Puebla, who reported significance, for $40 \mathrm{t} \mathrm{ha}^{-1}$ in yield tuber, at levels of 120 to 180 of N, 100 to 170 of $\mathrm{P}$ and up to $300 \mathrm{~kg} \mathrm{ha}^{-1}$ of K, under similar conditions of climate and soil type.

Alvarado et al. (2009) found that the application of 0, 150, 300,450 , and $600 \mathrm{~kg} \mathrm{ha}^{-1}$ of $\mathrm{P}_{2} 0_{5}$ in potato crop in Andosol soil, for two years, there was a significant response and a tuber yield of $16.39 \mathrm{tha}^{-1}$. 
Cuadro 1. Cuadrados medios y significancia estadística en las variables productivas en el experimento de papa. La Peñuela, municipio de Zinacantepec, México 2009.

Table 1. Mean square and statistical significance in the production variables in the experiment of potatoes. The Peñuela municipality of Zinacantepec, Mexico 2009.

\begin{tabular}{|c|c|c|c|c|c|c|c|c|c|}
\hline $\mathrm{FV}$ & $\mathrm{Gl}$ & RT & & RP & & $\mathrm{RS}$ & & RTE & \\
\hline Tratamiento & 17 & 117.8 & $* *$ & 56.8 & $*$ & 12.2 & $* *$ & 3.2 & NS \\
\hline Bloque & 3 & 107.6 & NS & 58.3 & NS & 11.4 & NS & 2.8 & NS \\
\hline Error & 51 & 41.6 & & 26.2 & & 3.7 & & 4.2 & \\
\hline CV $(\%)$ & & 25.9 & & 31.9 & & 30.7 & & 76.3 & \\
\hline
\end{tabular}

Las respuesta de rendimiento de 34 y $33 \mathrm{t} \mathrm{ha}^{-1}$ en dos tratamientos (cuatro y siete) para este experimento, resultaron más bajas que las obtenidas por Rueda (1991), en Puebla quien reportó significancia, para $40 \mathrm{t} \mathrm{ha}^{-1} \mathrm{en}$ rendimiento de tubérculo, en niveles de $\mathrm{N}$ de 120 a 180, $\mathrm{P}$ de 100 a 170 y K hasta $300 \mathrm{~kg} \mathrm{ha}^{-1}$, en condiciones semejantes de clima y tipo de suelo.

Alvarado et al. (2009) encontraron que con la aplicación de $0,150,300,450$, y $600 \mathrm{~kg} \mathrm{ha}^{-1} \mathrm{de}_{2} \mathrm{P}_{5}$ en el cultivo de papa en un Andosol, durante dos años, se obtuvo respuesta significativa y un rendimiento de tubérculo de $16.39 \mathrm{t} \mathrm{ha}^{-1}$.

De manera similar, al evaluar dos variedades de papa Devaux etal. (1997) no encontraron respuesta significativa: la variedad Sangema (Rosita) rindió $45 \mathrm{t} \mathrm{ha}^{-1} \mathrm{y}$ la variedad Waycha's tuvo un rendimiento de $35 \mathrm{t} \mathrm{ha}^{-1}$ de tubérculo, los factores evaluados fueron $80,160 \mathrm{~kg} \mathrm{ha}^{-1}$ de $\mathrm{N}$ y 80,160 , $240 \mathrm{~kg} \mathrm{ha}^{-1}$ de fósforo.

Más aun, las cantidades o dosis de fósforo que fueron necesarias para lograr las producciones de $34 \mathrm{t} \mathrm{ha}^{-1} \mathrm{y}$ de $33 \mathrm{t}$ $\mathrm{ha}^{-1}$ son consecuencia de la conocida fijación de fosfatos en suelos Andosol; es decir, la significancia revela la respuesta de la papa a estas dosis aplicadas, e indicaría un manejo estratégico de la fertilidad de suelos volcánicos a mediano plazo (Egawa, 1980).

La respuesta a nitrógeno en suelos volcánicos se debe a la limitada mineralización, de acuerdo a Muñoz y Wiezoreck (1978), por lo que, de acuerdo con los datos de significancia y la prueba de Tukey con un rango de 150 a $300 \mathrm{~kg} \mathrm{ha}^{-1} \mathrm{de} \mathrm{N}$ se cubre una respuesta adecuada en rendimiento para este nutriente.
Similarly, to evaluate two potato varieties Devaux et al. (1997) found no significant response: the variety Sangema (Rosita) yielded $45 \mathrm{t} \mathrm{ha}^{-1}$ and the variety Waycha's yielded $35 \mathrm{tha}^{-1}$, the evaluated factors were $80,160 \mathrm{~kg} \mathrm{ha}^{-1}$ of $\mathrm{N}$ and $80,160,240 \mathrm{~kg} \mathrm{ha}^{-1}$ of phosphorus.

Moreover, the phosphorus amounts or doses that were necessary to achieve the production of $34 \mathrm{t} \mathrm{ha}^{-1}$ and 33 $\mathrm{t} \mathrm{ha}^{-1}$ are consequence of the known phosphate fixing in Andosol soils; i.e. significance reveals the response of potato to the applied doses and would indicate a strategic management of volcanic soil fertility in the medium term (Egawa, 1980).

The response to nitrogen in volcanic soils is due to the limited mineralization, according to Munoz and Wiezoreck(1978), so that, according to the data significance and the Tukey test with a range of 150 to $300 \mathrm{~kg} \mathrm{ha}^{-1}$ of $\mathrm{N}$, is covered an adequate answer in yield to this nutrient.

The behavior on yield average of the variety Fianna, in its different categories, are shown in Table 2, with the Tukey test, which indicated a significant difference for total tuber (RT) in treatments four (300-350 to $70 \mathrm{~kg} \mathrm{ha}^{-1} \mathrm{~N}, \mathrm{P}$ and $\left.\mathrm{K}\right)$, and seven $\left(150-250-70 \mathrm{~kg} \mathrm{ha}^{-1} \mathrm{~N}, \mathrm{P}, \mathrm{K}\right)$.

The doses of nitrogen, phosphorus and potassium used in this investigation were higher than recommended for potato areas for the high lands of Puebla and Veracruz, which range between 60 and $90 \mathrm{~kg} \mathrm{ha}^{-1}$ of $\mathrm{N}$ and between 30 to $90 \mathrm{~kg}$ $\mathrm{ha}^{-1}$ of $\mathrm{K}_{2} \mathrm{O}$. In the case of phosphorus, doses were higher than those of the Neo volcanic axis and the Sierra Madre Oriental, where are recommended between 100 and $160 \mathrm{~kg}$ ha ${ }^{-1}$ of $\mathrm{P}_{2} \mathrm{O}_{5}$ Aguirre (1999), Rubio (2000). In this regard, in 
El comportamiento en rendimiento promedio de papa de la variedad Fianna, en sus diferentes categorías, se muestra en el Cuadro 2, con la prueba de Tukey, la cual indicó diferencia significativa para el total de tubérculo (RT), en los tratamientos cuatro $\left(300-350-70 \mathrm{~kg} \mathrm{ha}^{-1} \mathrm{~N}, \mathrm{PyK}\right)$, y siete (150-250-70 kg ha $\left.{ }^{-1} \mathrm{~N}, \mathrm{P}, \mathrm{K}\right)$. the 40's the amount of Padded in Andosol soils were 50-100 $\mathrm{kg} \mathrm{ha}^{-1}$ of $\mathrm{P}_{2} \mathrm{O}_{5}$, increasing during 1980-1990, up to $1000-1$ $500 \mathrm{~kg} \mathrm{ha}^{-1}$ of $\mathrm{P}_{2} \mathrm{O}_{5}$, and with a rationalization of the amount applied at levels of 450 to $600 \mathrm{~kg} \mathrm{ha}^{-1}$ of $\mathrm{P}_{2} \mathrm{O}_{5}$ that has been applied in recent years Alvarado et al. (2009). According to the above, the design of the treatments in this experiment was

Cuadro 2. Prueba de Tukey $(\alpha=0.05)$ en 18 tratamientos de fertilización en papa en La Peñuela, municipio de Zinacantepec, México, 2009.

Table 2. Tukey test $(\alpha=\mathbf{0 . 0 5})$ in 18 potato treatments of fertilization in La Peñuela, municipality of Zinacantepec, Mexico, 2009.

\begin{tabular}{cccccc}
\hline $\begin{array}{r}\text { Trat } \\
\text { Núm. }\end{array}$ & $\begin{array}{c}\mathrm{N}-\mathrm{P}-\mathrm{K} \\
(\mathrm{kgha}-\mathrm{l})\end{array}$ & $\mathrm{RT}$ & $\mathrm{RP}$ & $\mathrm{RS}$ & $\mathrm{RTE}$ \\
\hline 1 & $200-200-70$ & $21.5 \mathrm{ab}$ & $13.9 \mathrm{ab}$ & $5.2 \mathrm{ab}$ & 2.4 \\
2 & $250-250-70$ & $30.9 \mathrm{ab}$ & $21.0 \mathrm{a}$ & $6.2 \mathrm{ab}$ & 2.7 \\
3 & $200-300-70$ & $26.9 \mathrm{ab}$ & $17.4 \mathrm{ab}$ & $6.2 \mathrm{ab}$ & 3.2 \\
4 & $300-350-70$ & $34.3^{\mathrm{a}}$ & $22.3 \mathrm{a}$ & $8.7 \mathrm{ab}$ & 3.4 \\
5 & $300-250-70$ & $28.4 \mathrm{ab}$ & $17.6 \mathrm{ab}$ & $7.5 \mathrm{ab}$ & 3.4 \\
6 & $300-300-70$ & $28.1 \mathrm{ab}$ & $16.3 \mathrm{ab}$ & $8.9 \mathrm{ab}$ & 3.0 \\
7 & $150-250-70$ & $33.7 \mathrm{a}$ & $22.4 \mathrm{a}$ & $8.4 \mathrm{ab}$ & 2.9 \\
8 & $200-000-70$ & $22.2 \mathrm{ab}$ & $14.8 \mathrm{ab}$ & $5.8 \mathrm{ab}$ & 1.6 \\
9 & $300-300-00$ & $22.9 \mathrm{ab}$ & $16.8 \mathrm{ab}$ & $3.9 \mathrm{~b}$ & 1.2 \\
10 & $300-300-140$ & $19.0 \mathrm{ab}$ & $13.0 \mathrm{ab}$ & $4.1 \mathrm{ab}$ & 1.9 \\
11 & $300-300-70$ & $14.5 \mathrm{ab}$ & $8.4 \mathrm{~b}$ & $4.8 \mathrm{ab}$ & 1.3 \\
12 & $300-300-70$ & $17.6 \mathrm{ab}$ & $9.5 \mathrm{ab}$ & $5.6 \mathrm{ab}$ & 2.6 \\
13 & $300-300-70$ & $22.4 \mathrm{ab}$ & $15.8 \mathrm{ab}$ & $4.6 \mathrm{ab}$ & 2.1 \\
14 & $300-300-70$ & $21.1 \mathrm{ab}$ & $14.0 \mathrm{ab}$ & $5.2 \mathrm{ab}$ & 1.9 \\
15 & $300-400-210$ & $25.7 \mathrm{ab}$ & $15.4 \mathrm{ab}$ & $4.9 \mathrm{ab}$ & 5.4 \\
16 & $250-250-70$ & $29.2 \mathrm{ab}$ & $17.1 \mathrm{ab}$ & $9.1 \mathrm{a}$ & 3.0 \\
17 & $250-450-70$ & $27.7 \mathrm{ab}$ & $16.6 \mathrm{ab}$ & $8.2 \mathrm{ab}$ & 2.9 \\
18 & $350-450-70$ & $22.7 \mathrm{ab}$ & $15.4 \mathrm{ab}$ & $4.9 \mathrm{ab}$ & 2.4 \\
\end{tabular}

Trat $=$ tratamiento; $\mathrm{RT}=$ rendimiento total de tubérculo; $\mathrm{RP}=$ rendimiento de primera categoría; $\mathrm{RS}=$ rendimiento de segunda categoría; $\mathrm{RTE}=$ rendimiento de tercera categoría $\left(\mathrm{t} \mathrm{ha}^{-1}\right)$. Tukey $(\alpha=0.05 \%)$ literales similares no difieren estadísticamente; DMS $=$ diferencia mínima significativa $\left(t\right.$ ha $\left.^{-1}\right)$.

Las dosis de nitrógeno, fósforo y potasio utilizadas en esta investigación, fueron superiores a las recomendadas para las zonas paperas de las sierras de Puebla y Veracruz, las cuales fluctúan entre 60 y $90 \mathrm{~kg} \mathrm{ha}^{-1}$ de $\mathrm{N}$ y entre 30 y $90 \mathrm{~kg} \mathrm{ha}^{-1} \mathrm{de}$ $\mathrm{K}_{2}$. Para el caso de fósforo las dosis fueron más altas que las de la sierra del eje Neovolcánico y que las de la sierra madre Oriental, donde se recomiendan entre 100 y $160 \mathrm{~kg} \mathrm{ha}^{-1} \mathrm{de}$ $\mathrm{P}_{2} \mathrm{O}_{5}$ Aguirre (1999), Rubio (2000). Al respecto, en los años 40's las cantidades de $P$ adicionadas en Andosoles eran de 50 $-100 \mathrm{~kg} \mathrm{ha}^{-1}$ de $\mathrm{P}_{2} \mathrm{O}_{5}$, incrementándose, durante 1980-1990, at range 200-450 kg ha-1 $\mathrm{P}_{2} 0_{5}$, indicating reasonable levels in the treatments applied. Phosphorus doses, according to Aguilar et al. (2000), followed the recommendations to achieve a potential yield.

Meanwhile Berrios (2010) reported yields of $37 \mathrm{t} \mathrm{ha}^{-1}$ of tuber, in complete combination of nutrients (NPK), $15 \mathrm{tha}^{-1}$ , without N (with PK), 29 tha $^{-1}$ without P (with NK), and 29.2 tha ${ }^{-1}$ withoutK (with NP) for which, used a general treatment of $\mathrm{N}: 240, \mathrm{P}: 65, \mathrm{~K}: 150 \mathrm{~kg} \mathrm{ha}^{-1}$. 
hasta $1000-1500 \mathrm{~kg} \mathrm{ha}^{-1} \mathrm{de}_{2} 0_{5}$, y con una racionalización de la cantidad aplicada a niveles de $450-600 \mathrm{~kg} \mathrm{ha}^{-1} \mathrm{de}_{2} \mathrm{O}_{5}$ que se ha aplicado en los últimos años Alvarado et al. (2009). De acuerdo con lo anterior, el diseño de los tratamientos en éste experimento, se ubicó en rango de 200-450 kg ha- $\mathrm{P}_{2} 0_{5}$, indicando niveles racionales en los tratamientos aplicados. Las dosis de fósforo, de acuerdo con Aguilar et al. (2000), siguieron las recomendaciones para alcanzar un rendimiento potencial.

Por su parte Berrios (2010), reportó rendimientos de 37 tha $^{-1}$ de tubérculo, en combinación completa de nutrientes (NPK), 15 tha $^{-1}, \sin \mathrm{N}(\operatorname{con} \mathrm{PK}), 29 \mathrm{tha}^{-1} \sin \mathrm{P}(\operatorname{con} \mathrm{NK}), \mathrm{y} 29.2 \mathrm{tha}^{-1}$ $\sin \mathrm{K}$ (con NP) para lo cual utilizaron un tratamiento general de N: 240, P: 65, K: $150 \mathrm{Kg} \mathrm{ha}^{-1}$.

\section{Respuesta gráfica método Turrent}

Las respuestas del cultivar Fianna al fertilizante nitrogenado, fosfórico y potásico indican que la curva N-350-70 representa la respuesta de papa al nitrógeno (Figura 1) cuando hay constantes $350 \mathrm{~kg} \mathrm{ha}^{-1}$ de $\mathrm{P}$ y $70 \mathrm{~kg} \mathrm{ha}^{-1}$ de K. También se observa que con $200 \mathrm{~kg} \mathrm{ha}^{-1}$ de nitrógeno se elimina la deficiencia de éste elemento.

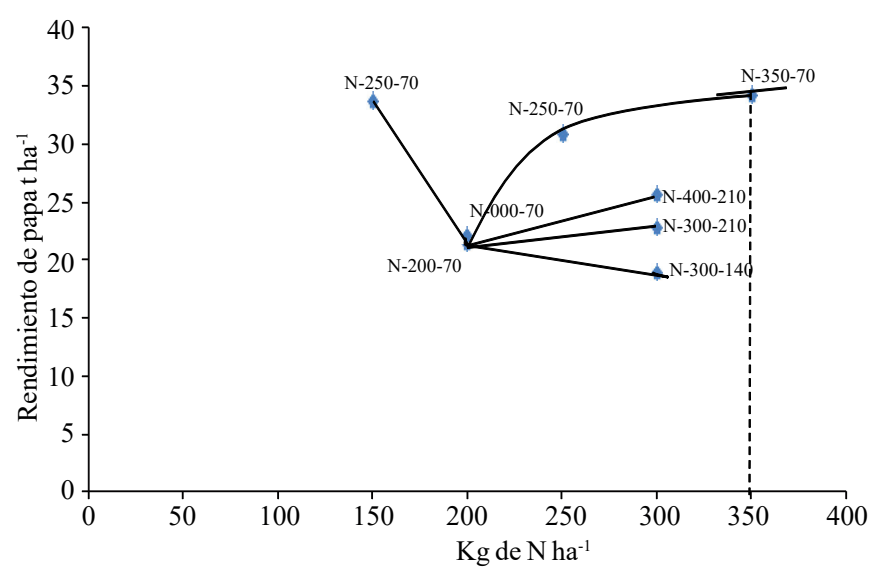

Figura 1. Respuesta del cultivo de la papa a nitrógeno. La Peñuela, Municipio de Zinacantepec. Estado de México. 2009.

Figure 1. Response of potato crop to nitrogen. La Peñuela, municipality of Zinacantepec. State of Mexico.2009.

Se observa que con $200 \mathrm{~kg} \mathrm{ha}^{-1}$ de fósforo se cubre la deficiencia, cuando el nitrógeno y el potasio, estén en 200 $\mathrm{kg} \mathrm{ha}^{-1}$ y $70 \mathrm{~kg} \mathrm{ha}^{-1}$ (Figura 2), y cuando los factores de nitrógeno y potasio estén en el nivel del factorial, $300 \mathrm{~kg}$ ha ${ }^{-1}$ de nitrógeno y $70 \mathrm{~kg} \mathrm{ha}^{-1}$ de potasio. Es de señalar que la dosis de fósforo de acuerdo a Berrios et al. (2010), se ajusta a los resultados obtenidos en este experimento.

\section{Response Turrent graphical method}

The responses of Fianna potato variety to nitrogen, potassium and phosphoric fertilizers indicate that the N-350-70 curve, represents the response of potato to nitrogen (Figure 1) when constant $350 \mathrm{~kg} \mathrm{ha}^{-1}$ of $\mathrm{P}$ and $70 \mathrm{~kg} \mathrm{ha}^{-1}$ of K. It is also noted that with $200 \mathrm{~kg} \mathrm{ha}^{-1}$ of nitrogen is eliminated the deficiency of this nutrient.

Note that with $200 \mathrm{~kg} \mathrm{ha}^{-1}$ of phosphorus is covered the deficiency, when nitrogen and potassium, are in $200 \mathrm{~kg} \mathrm{ha}^{-1}$ and $70 \mathrm{~kg} \mathrm{ha}^{-1}$ (Figure 2), and when the factors are nitrogen and potassium in factorial level, $300 \mathrm{~kg} \mathrm{ha}^{-1}$ of nitrogen and $70 \mathrm{~kg} \mathrm{ha}^{-1}$ of potassium. It should be noted that the dose of phosphorus according to Berrios et al. (2010), is consistent with the results obtained in this experiment.

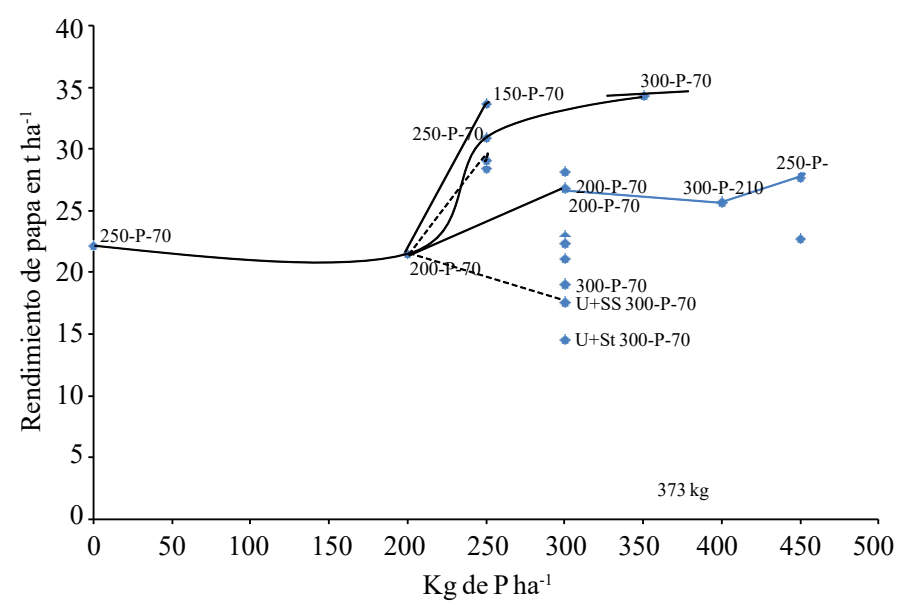

Figura 2. Respuesta de niveles de fósforo en el cultivo de papa. La Peñuela, municipio de Zinacantepec, Estado de México., 2009.

Figure 2. Response of phosphorus levels in potato crop. La Peñuela, municipality of Zinacantepec, State of Mexico, 2009.

It was also observed the response to potassium, when there are $200 \mathrm{~kg} \mathrm{ha}^{-1}$ of nitrogen and $200 \mathrm{~kg} \mathrm{ha}^{-1}$ of phosphorus (Figure 3). In the case of $140 \mathrm{~kg} \mathrm{ha}^{-1}$ of phosphorus, yield decreased and for $210 \mathrm{kgha}^{-1}$ of potassium, slightly increases, without reaching curve levels of $350-350-\mathrm{K}\left(34.3 \mathrm{tha}^{-1}\right)$.

With yield data, proceeded to graphically obtaining the approximate solution to optimum economic treatment for unlimited capital (Figures 1,2, and 3); by placing the slopes of the relation of price factor-product for $\mathrm{n} / \mathrm{y}=3.4, \mathrm{p} / \mathrm{y}=7.5$, $\mathrm{k} / \mathrm{y}=7.8$ and $\mathrm{d} / \mathrm{y}=717.9(\mathrm{n}=\$ 4.6, \mathrm{p}=\$ 8.6, \mathrm{k}=\$ 9.0, \mathrm{~d}=$ $\$ 827.0, y=\$ 1,152)$ same that indicate the value of nutrient per kilogram of potato; where y represents the value of 1 
También se observó la respuesta al potasio, cuando existen $200 \mathrm{~kg} \mathrm{ha}^{-1}$ de nitrógeno y $200 \mathrm{~kg} \mathrm{ha}^{-1}$ de fósforo (Figura 3). En el caso de $140 \mathrm{~kg} \mathrm{ha}^{-1}$ de fósforo, disminuyó el rendimiento y para $210 \mathrm{~kg} \mathrm{ha}^{-1}$ de potasio sube ligeramente, sin alcanzar los niveles de la curva 350-350-K (34.3 tha-1 $)$.

Con los datos de rendimiento se procedió a la obtención de manera gráfica a la solución aproximada al tratamiento óptimo económico de capital ilimitado (Figuras 1, 2, y 3); al colocar las pendientes de las relaciones de precios factor producto para $\mathrm{n} / \mathrm{y}=3.4, \mathrm{p} / \mathrm{y}=7.5, \mathrm{k} / \mathrm{y}=7.8 \mathrm{yd} / \mathrm{y}=717.9(\mathrm{n}=\$ 4.6, \mathrm{p}=\$ 8.6$, $\mathrm{k}=\$ 9.0, \mathrm{~d}=\$ 827.0, \mathrm{y}=\$ 1.152)$ mismas que nos indican el valor del nutriente por kilogramo de papa; donde y representa el valor de $1 \mathrm{~kg}$ de papa en campo. Las soluciones por tanto involucran la pendiente similar a la pendiente de la relación precios factor - producto. En el caso de nitrógeno la curva 300-300-K cumple ese requisito, al igual que las curvas de fósforo y potasio (300-P-70 y 350-350-K).

Respecto al método gráfico, resultados para la sierra veracruzana Aguilar et al. (2000), en la variedad Tollocan, con la dosis 80-200-80 $\mathrm{kg} \mathrm{ha}^{-1} \mathrm{deN}, \mathrm{P}_{2} \mathrm{O}_{5} \mathrm{yK}_{2} 0$, registró 13.4 tha $^{-1}$, y la variedad Puebla, con 80-150-50 $\mathrm{kg} \mathrm{ha}^{-1}$ de N, $\mathrm{P}_{2} \mathrm{O}_{5}$ y K $\mathrm{K}_{2} \mathrm{O}$ rindió 12.1 tha $^{-1}$ ambos rendimientos y dosis, menores que los reportados en este experimento. Los resultados obtenidos con el método gráfico Turrent (1981), se comprueban enseguida con el método discreto que se presenta más adelante.

Los resultados para los fertilizantes comerciales utilizados (Figura 4) indicaron que el mejor rendimiento de tubérculo de papa, fue para, difosfato de amonio (18-46-00\% de N, $\left.\mathrm{P}_{2} \mathrm{O}_{5}, \mathrm{~K}_{2} \mathrm{O}\right)$, fosfonitrato $(33 \% \mathrm{~N})$ y cloruro de potasio $\mathrm{KCl}$ $\left(60 \%, \mathrm{~K}_{2} 0\right)$. Enseguida respondió el triple 16; a continuación sulfato de amonio, superfosfato de calcio simple y cloruro de potasio. Las fuentes de menor rendimiento fueron la urea, con superfosfato de calcio triple y cloruro de potasio.

\section{Análisis económico}

En el análisis económico, practicado con el procedimiento discreto, resultó que el cultivo de papa bajo condiciones de riego presentó el máximo ingreso neto (In) en el tratamiento cuatro, con un valor de $\$ 194832.60$ ha, así como una mayor tasa de retorno al capital total (tr de 429.1). Por lo tanto, ésta se asocia al tratamiento óptimo económico de capital ilimitado (TOECI), utilizando las fuentes comerciales de fertilizante: difosfato de amonio (18-46-00\% unidades de $\mathrm{N}, \mathrm{P}$ y K, fosfonitrato (33\%) y cloruro de potasio para 300 350-70 unidades de $\mathrm{N}, \mathrm{P}_{2} \mathrm{O}_{5}$ y $\mathrm{K}_{2} \mathrm{O}$. $\mathrm{kg}$ of potatoes in the field. The solutions therefore involve the slope, similar to the slope of the price factor - product. In the case of the Nitrogen curve 300 to $300-\mathrm{K}$ meets this condition, as the curves of phosphorus and potassium (300P-70 and 350-350-K).

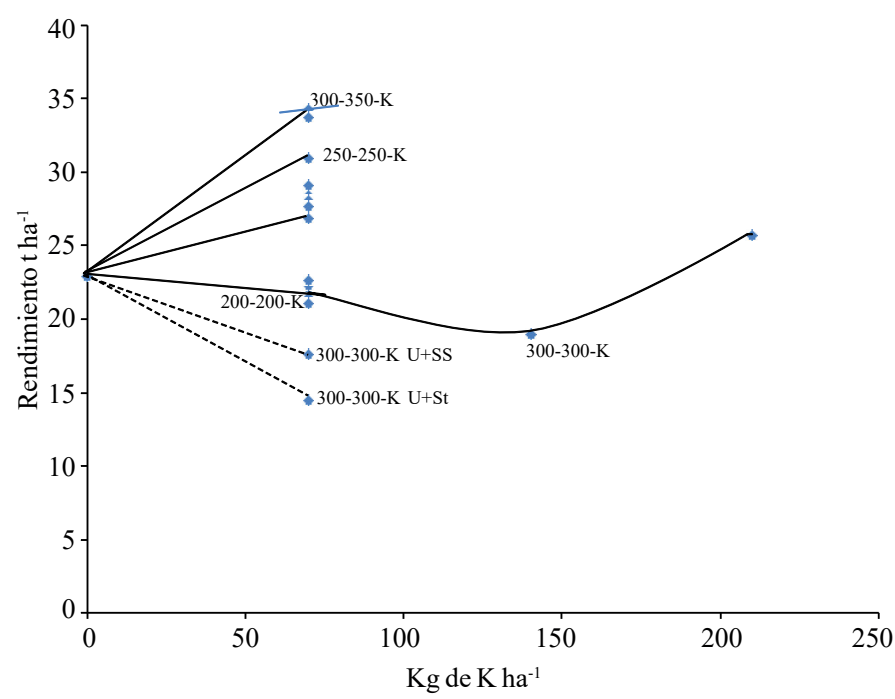

Figura 3. Respuesta en niveles de potasio en el cultivo de papa. La Peñuela, municipio de Zinacantepec, Estado de México 2009.

Figure 3. Response levels of potassium in the potato crop. La Peñuela, municipality of Zinacantepec, State of Mexico 2009.

Regarding the graphical method, results for the highlands in Veracruz Aguilar et al. (2000), in the variety Tollocan, with doses $80-200-80 \mathrm{~kg} \mathrm{ha}^{-1}$ of N, $\mathrm{P}_{2} 0_{5}$ and $\mathrm{K}_{2} 0$, recorded $13.4 \mathrm{t}$ $\mathrm{ha}^{-1}$; and the variety Puebla, with 80-150-50 $\mathrm{kg} \mathrm{ha}^{-1}$ of N, $\mathrm{P}_{2} \mathrm{O}_{5}$ and $\mathrm{K}_{2} \mathrm{O}$ yielded $12.1 \mathrm{tha}^{-1}$, both yields and doses are lower than those reported in this experiment. The results obtained with the Turrent graphical method (1981), are tested at once with the discrete method presented below.

The results for commercial fertilizers used (Figure 4) indicated that the best potato tuber yield was for, ammonium diphosphate (18-46-00\% of N, $\mathrm{P}_{2} \mathrm{O}_{5}, \mathrm{~K}_{2} \mathrm{O}$ ), phosphonitrate $(33 \% \mathrm{~N})$ and chloride potassium $\mathrm{KCl}\left(60 \%, \mathrm{~K}_{2} 0\right)$. Followed 16 triple, ammonium sulfate, single calcium superphosphate and potassium chloride. Lower yield sources were urea along with calcium triple superphosphate and potassium chloride.

\section{Economic analysis}

In the economic analysis, conducted with the discrete procedure, it resulted that the potato crop under irrigated conditions showed the maximum net income (In) in 


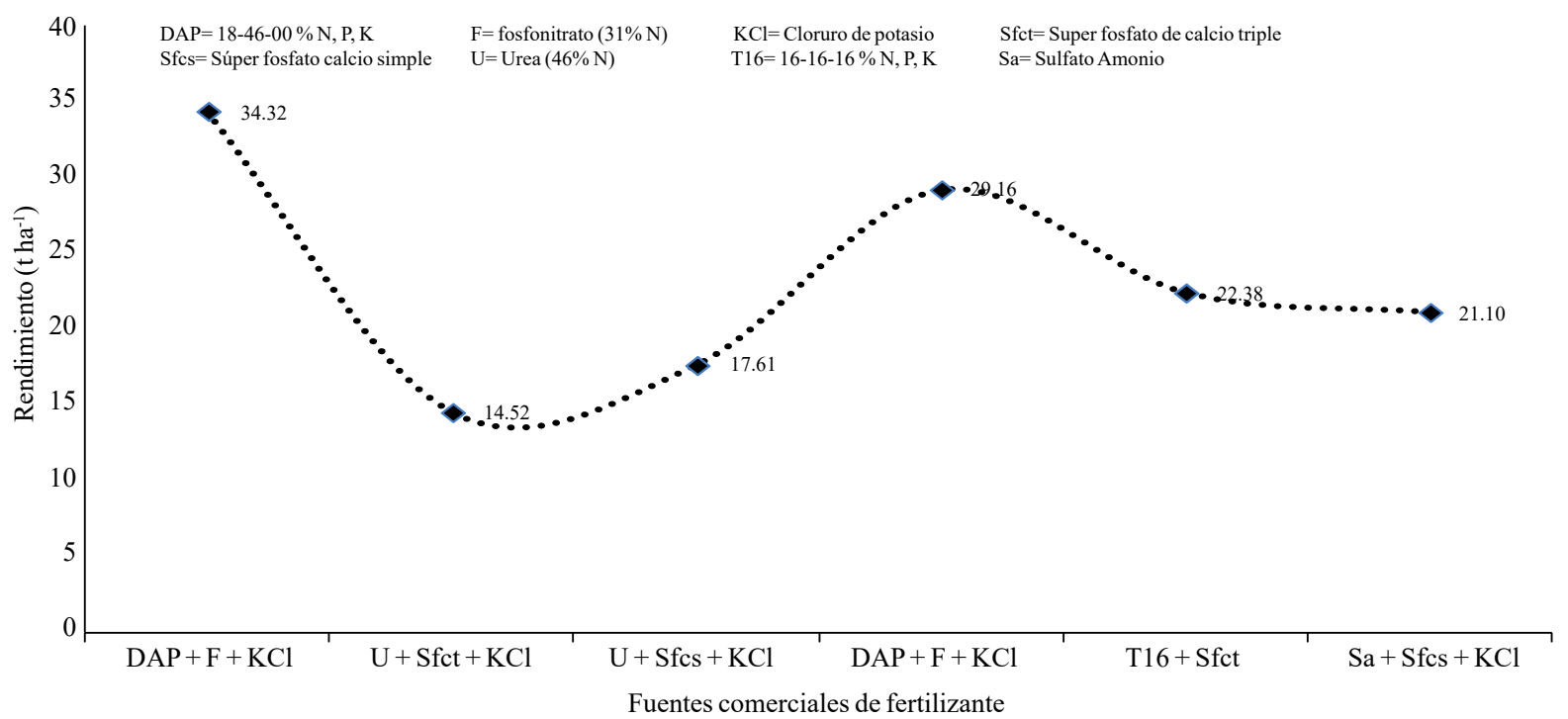

Figura 4. Respuesta de las fuentes comerciales de fertilización en el cultivo de papa. La Peñuela municipio de Zinancantepec, Estado de México 2009.

Figure 4. Response of commercial fertilizers on potato crop. La Peñuela, municipality of Zinancantepec, State of Mexico 2009.

Para el caso del tratamiento óptimo económico de capital limitado (TOECL), el máximo ingreso neto fue de \$194 333.6 ha con el tratamiento siete, correspondiendo a 150$250-70 \mathrm{~kg}$ ha unidades de $\mathrm{N}, \mathrm{P}_{2} \mathrm{O}_{5}, \mathrm{~K}_{2} \mathrm{O}$ (Cuadro 4) con una tasa interna de retornó al capital total de 466. El método utilizado por Volke (1982) indicó como otra alternativa para tratamiento de capital limitado con $\$ 173247.8$ ha al tratamiento dos (250-250-70 unidades de $\mathrm{N}, \mathrm{P}_{2} \mathrm{O}_{5} \mathrm{y}$, $\mathrm{K}_{2} \mathrm{O}$ ), con una tasa de retorno al capital total de 401.1 (Cuadro 4). treatment four, with a value of $\$ 194832.60$ ha, also a higher rate of return to total capital(tr of 429.1). Thus, this is associated to the optimum economic treatment for unlimited capital (TOECI), using commercial fertilizer: ammonium diphosphate (18-46-00\% units of N, P and K, phosphonitrate (33\%) and potassium chloride for 300-350-70 units of N, $\mathrm{P}_{2} \mathrm{O}_{5}$ and $\mathrm{K}_{2} \mathrm{O}$.

In the case of the optimum economic treatment for limited capital (TOECL), the maximum net income was \$194, 333.6 ha with treatment seven, corresponding to $150-250$ -

Cuadro 4. Análisis económico para rendimiento total de tubérculo en tratamientos de fertilización. La Peñuela, municipio de Zinacantepec, Estado de México 2009.

Table 4. Economic analysis for total tuber yield on fertilization treatments. La Peñuela, municipality of Zinacantepec, State of Mexico 2009.

\begin{tabular}{ccccccccc}
\hline $\begin{array}{c}\text { Núm } \\
\text { Trat }\end{array}$ & $\begin{array}{c}\mathrm{N} \text { P } \\
\mathrm{kg} \mathrm{ha}^{-1}\end{array}$ & $\begin{array}{c}\mathrm{tha}^{-1} \\
\mathrm{RT}\end{array}$ & $\begin{array}{c}\$ 7000 / \mathrm{t} \\
\mathrm{It}\end{array}$ & $\mathrm{Cf}$ & $\mathrm{cv}$ & $\mathrm{ct}$ & $\mathrm{In}=\mathrm{It}-\mathrm{ct}$ & $\begin{array}{c}\text { tr } \\
(\mathrm{In} / \mathrm{ct}) \times 100\end{array}$ \\
\hline 1 & $200-200-70$ & 21.5 & $\$ 150430$ & $\$ 34760$ & $\$ 6960.6$ & $\$ 41720.6$ & $\$ 108709.4$ & 260.6 \\
2 & $250-250-70$ & 30.9 & $\$ 216440$ & $\$ 34760$ & $\$ 8432.2$ & $\$ 43192.2$ & $\$ 173247.8$ & 401.1 \\
3 & $200-300-70$ & 26.9 & $\$ 188020$ & $\$ 34760$ & $\$ 8422.0$ & $\$ 43182.0$ & $\$ 144838.0$ & 335.4 \\
4 & $300-350-70$ & 34.3 & $\$ 240240$ & $\$ 34760$ & $\$ 10647.4$ & $\$ 45407.4$ & $\$ 194832.6$ & 429.1 \\
5 & $300-250-70$ & 28.4 & $\$ 199080$ & $\$ 34760$ & $\$ 9172.8$ & $\$ 43932.8$ & $\$ 155147.2$ & 353.1 \\
6 & $300-300-70$ & 28.1 & $\$ 196910$ & $\$ 34760$ & $\$ 9907.8$ & $\$ 44667.8$ & $\$ 152242.2$ & 340.8 \\
7 & $150-250-70$ & 33.7 & $\$ 236040$ & $\$ 34760$ & $\$ 6946.4$ & $\$ 41706.4$ & $\$ 194333.6$ & 466.0 \\
8 & $200-000-70$ & 22.2 & $\$ 155120$ & $\$ 34760$ & $\$ 4020.0$ & $\$ 38780.0$ & $\$ 116340.0$ & 300.0 \\
\hline
\end{tabular}

Núm. trat $=$ número de tratamiento; $\mathrm{RT}=$ rendimiento total promedio de tubérculo; $\mathrm{It}=$ ingreso total $=\mathrm{RT}$ x $\$ 7 \mathrm{000} ; \mathrm{cf}=\cos$ to fijo $=\$ 34760 ; \mathrm{cv}=\mathrm{costo}$ variable $=\mathrm{nN} \times \mathrm{pP} \times$ $\mathrm{kK} ; \mathrm{ct}=$ costo total $=\mathrm{cf}+\mathrm{cv} ; \mathrm{In}=$ ingreso neto $=\mathrm{It}-\mathrm{ct} ; \mathrm{tr}=$ tasa de retorno a capital total $=(\mathrm{In} / \mathrm{ct}) * 100$. 
Cuadro 4. Análisis económico para rendimiento total de tubérculo en tratamientos de fertilización. La Peñuela, municipio de Zinacantepec, Estado de México 2009 (Continuación).

Table 4. Economic analysis for total tuber yield on fertilization treatments. La Peñuela, municipality of Zinacantepec, State of Mexico 2009 (Continuation).

\begin{tabular}{ccccccccc}
\hline $\begin{array}{c}\text { Núm } \\
\text { Trat }\end{array}$ & $\begin{array}{c}\mathrm{N} \text { P K } \\
\mathrm{kg} \mathrm{ha}^{-1}\end{array}$ & $\begin{array}{c}\mathrm{tha}^{-1} \\
\mathrm{RT}\end{array}$ & $\begin{array}{c}\$ 7000 / \mathrm{t} \\
\mathrm{It}\end{array}$ & $\mathrm{Cf}$ & $\mathrm{cv}$ & $\mathrm{ct}$ & $\mathrm{In}=\mathrm{It}-\mathrm{ct}$ & $\begin{array}{c}\text { tr } \\
(\mathrm{In} / \mathrm{ct}) \times 100\end{array}$ \\
\hline 9 & $300-300-00$ & 22.9 & $\$ 160440$ & $\$ 34760$ & $\$ 8827.2$ & $\$ 43587.2$ & $\$ 116852.8$ & 268.1 \\
10 & $300-300-140$ & 19.0 & $\$ 133000$ & $\$ 34760$ & $\$ 10951.8$ & $\$ 45711.8$ & $\$ 87288.2$ & 191.0 \\
11 & $300-300-70$ & 14.5 & $\$ 101640$ & $\$ 34760$ & $\$ 12034.6$ & $\$ 46794.6$ & $\$ 54845.4$ & 117.2 \\
12 & $300-300-70$ & 17.6 & $\$ 123270$ & $\$ 34760$ & $\$ 9018.7$ & $\$ 43778.7$ & $\$ 79491.3$ & 181.6 \\
13 & $300-300-70$ & 22.4 & $\$ 156660$ & $\$ 34760$ & $\$ 6372.0$ & $\$ 41132.0$ & $\$ 115528.0$ & 280.9 \\
14 & $300-300-70$ & 21.1 & $\$ 147700$ & $\$ 34760$ & $\$ 11879.2$ & $\$ 46639.2$ & $\$ 101060.8$ & 216.7 \\
15 & $300-400-210$ & 25.7 & $\$ 179970$ & $\$ 34760$ & $\$ 12509.8$ & $\$ 47269.8$ & $\$ 132700.2$ & 280.7 \\
16 & $350-250-70$ & 29.2 & $\$ 204120$ & $\$ 34760$ & $\$ 9568.7$ & $\$ 44328.7$ & $\$ 159791.2$ & 360.5 \\
17 & $350-450-70$ & 27.2 & $\$ 190260$ & $\$ 34760$ & $\$ 12168.2$ & $\$ 46928.2$ & $\$ 143331.8$ & 305.4 \\
18 & $350-450-70$ & 22.7 & $\$ 158970$ & $\$ 34760$ & $\$ 12854.0$ & $\$ 47614.0$ & $\$ 111356.0$ & 233.9 \\
\hline
\end{tabular}

Núm. trat $=$ número de tratamiento; $\mathrm{RT}=$ rendimiento total promedio de tubérculo; $\mathrm{It}=$ ingreso total $=\mathrm{RT} \times \mathrm{x} \$ 7000 ; \mathrm{cf}=\operatorname{costo}$ fijo $=\$ 34760 ; \mathrm{cv}=\mathrm{cos}$ to variable $=\mathrm{nN} \times \mathrm{pP} \times$ $\mathrm{kK} ; \mathrm{ct}=$ costo total $=\mathrm{cf}+\mathrm{cv} ; \mathrm{In}=$ ingreso neto $=\mathrm{It}-\mathrm{ct} ; \mathrm{tr}=$ tasa de retorno a capital total $=(\mathrm{In} / \mathrm{ct}) * 100$.

\section{Precios considerados:}

a) $\$ 4.6, \$ 8.6$ y $\$ 9.0$ por $\mathrm{kg}$ de $\mathrm{N}, \mathrm{P}_{2} \mathrm{O}_{5}$ y $\mathrm{K}_{2} \mathrm{O}$ tratamientos: 1 a $10,15-18$

b) $\$ 5.8, \$ 2.8$ y $\$ 9.0$ por kg de $\mathrm{N}, \mathrm{P}_{2} \mathrm{O}_{5}, \mathrm{~K}_{2} \mathrm{O}$ tratamientos. 11

c) $\$ 5.8, \$ 4.8 \$ 9.0$ por kg de N, $\mathrm{P}_{2} \mathrm{O}_{5}$ tratamientos $\left.12 \mathrm{~d}\right) \$ 5.4$ $\$ 4.8$ por $\mathrm{Kg}$ de $\mathrm{N}, \mathrm{P}_{2} \mathrm{O}_{5} \mathrm{~K}_{2} \mathrm{O}$ Trat. 13

e) $\$ 4.6, \$ 2.8, \$ 9.0$ por $\mathrm{kg}$ de N, P2O5, K20 Tratamiento 14

$\mathrm{ct}=\mathrm{cf}+\mathrm{cv} \quad \mathrm{In}=$ ingreso neto $=$ It $-\mathrm{ct} \quad \mathrm{tr}=$ tasa de retorno al capital. $=(\mathrm{In} / \mathrm{ct}) \times 100$.

\section{Conclusiones}

Para las condiciones de riego en un suelo Andosol en la comunidad de la Peñuela, en el municipio de Zinacantepec, Estado México, el promedio en rendimiento de tubérculo de la variedad de papa Fianna, fue superior a treinta toneladas por ha ${ }^{-1}$, en particular el tratamiento cuatro superó al resto de tratamientos. El análisis estadístico ratificó los resultados con alta significancia para rendimiento total de tubérculo, y la primera, y segunda categoría.

La variedad de papa Fianna presentó una adecuada respuesta a la fertilización mineral con fuentes comerciales de fertilización de alta solubilidad bajo condiciones de
$70 \mathrm{~kg}$ ha units of $\mathrm{N}, \mathrm{P}_{2} \mathrm{O}_{5}, \mathrm{~K}_{2} \mathrm{O}$ (Table 4) with an internal rate of return to total capital of 466 . The method used by Volke (1982) indicated as other alternative to treatment for limited capital with $\$ 173247.8$ ha, to treatment two (250-250-70 units of $\mathrm{N}, \mathrm{P}_{2} \mathrm{O}_{5}$ and $\mathrm{K}_{2} \mathrm{O}$ ), with a return rate to total capital of 401.1 (Table 4 ).

\section{Prices considered:}

a) $\$ 4.6, \$ 8.6$ and $\$ 9.0$ per kg of $\mathrm{N}, \mathrm{P}_{2} \mathrm{O}_{5}$ and $\mathrm{K}_{2} \mathrm{O}$ treatments: 1 to $10,15-18$

b) $\$ 5.8, \$ 2.8$ and $\$ 9.0$ per kg of N, $\mathrm{P}_{2} \mathrm{O}_{5}$ and $\mathrm{K}_{2} \mathrm{O}$ treatments: 11

c) $\$ 5.8 \$ 4.8 \$ 9.0$ per kg of N, $\mathrm{P}_{2} \mathrm{O}_{5}$ treatments $\left.12 \mathrm{~d}\right) \$ 5.4$ $\$ 4.8$ per kg of N, $\mathrm{P}_{2} \mathrm{O}_{5}, \mathrm{~K}_{2} \mathrm{O}$ Trat 13

e) $\$ 4.6, \$ 2.8, \$ 9.0$ per kg of $\mathrm{N}, \mathrm{P}_{2} \mathrm{O}_{5}, \mathrm{~K}_{2} 0$ Treatment 14

$\mathrm{ct}=\mathrm{cf}+\mathrm{cv} \quad \mathrm{In}=$ net income $=\mathrm{It}-\mathrm{ct} \quad \mathrm{tr}=$ rate of return to capital. $=(\operatorname{In} / \mathrm{ct}) \times 100$.

\section{Conclusions}

For irrigation conditions in Andosol soils in the locality of La Peñuela, municipality of Zinacantepec, State of Mexico, the average in tuber yield of potato variety Fianna, was higher than thirty tons per ha ${ }^{-1}$, in particular treatment four 
riego, específicamente para difosfato de amonio (18$46-00 \%)$, fosfonitrato $(33 \% \mathrm{~N})$ y cloruro de potasio $\mathrm{KCl}$ $\left(60 \% \mathrm{~K}_{2} 0\right)$.

La dosis óptima de capital ilimitado correspondió al tratamiento cuatro (300-350-70 unidades ha de N, P y K), y para capital limitado el tratamiento siete (150-250-70 unidades ha de N, P y K.)

Se concluye por tanto, que existió respuesta en rendimiento en la variedad Fianna, por la aplicación de difosfato de amonio, fosfonitrato y cloruro de potasio; y que dicha respuesta se asoció con las dosis óptimas de capital limitado e ilimitado en la comunidad de la Peñuela, Estado de México para un suelo Andosol.

\section{Literatura citada}

Aguilar,A.J.L.; López,M.R; Volke,H.VyKhalil, G.A. 2000. Fertilización en papa y su efecto residual en maíz en dos agrosistemas de la sierra veracruzana. México. Terra. 18(1):71-81.

Aguirre, Y. G. 1999. Evaluación de fuentes de fósforo en el rendimiento del cultivo de papa con énfasis en roca fosfatada y fuentes orgánicas. Anales agrarios Universidad Agraria la Molina. (consultado enero, 2011). http//tumi.lamolina.edu.pe/resumen /anales/1999 92.pdf. 223-323.

Alvarado, P. A.; Iturriaga, I.; Smith, J. T.; Ureña, J. M. y Portuguez, E. 2009. Efecto de la fertilización con fósforo sobre el rendimiento y la absorción de nutrimentos de la papa en un Andisol de Juan Viñas, Costa Rica. Agronomía Costarricense. Universidad de Costa Rica. 33(1):45-61.

Bertsch, F. 2003. Absorción de nutrientes por los cultivos. San José de Costa Rica. Asociación Costarricense de la Ciencia del Suelo (ACCS). $307 \mathrm{p}$.

Berrios, M. y Elias, E. 2010. Seminario de nutrición en papa. Optimización nutrición Nitrogenada. In: XIII Congreso nacional de papa, Tlapa, Jalisco. Conpapa. 57-69 pp.

Cochram, W. G. y Cox, G. M. 2004. Diseños experimentales. Trillas. $6^{a}$ (Ed.). México D. F. 661 pp.

Devaux, A. J.; Vallejos, R. y Ramos, H. J. 1997. Respuesta agronómica de dos variedades de papa (Solanum tuberosum spp. y var andigenum) a diferentes niveles de fertilización mineral. Rev. Latinoaméricana de la papa. 9(10):123-139.

Egawa, T. 1980. Propiedades de los suelos derivados de cenizas volcánicas. In: Ishizuka, Y. y Black, C. A. (Eds.). Suelos derivados de cenizas volcánicas en Japón. CIMMYT, México D. F. $14-67$ pp.

Franco, M. S.; Cadena, R. A.; González, T. E. y Orozco, H. 2004. Atlas Estado de México. Gobierno del Estado de México. Dirección General de Comunicación Social (DGCS). Universidad Autónoma del Estado de México (UAEM). 85 p.

García, E. 1981. Modificación al sistema de clasificación climática de Köppen. Instituto de Geografía, Universidad Autónoma de México(UNAM). México, D. F. 61 p. outperformed all other treatments. The statistical analysis confirmed the results with high significance for total tuber yield, and the first and second category.

Potato variety Fianna showed a suitable response to mineral fertilization with commercial fertilizers of high solubility under irrigation conditions, specifically for ammonium diphosphate (18-46-00\%) phosphonitrate $(33 \% \mathrm{~N})$ and potassium chloride $\mathrm{KCl}\left(60 \% \mathrm{~K}_{2} 0\right)$.

The optimal dose of unlimited capital corresponded to treatment to four (300-350-70 units ha of N, P and K), and for limited capital treatment seven (150-250-70 units ha of $\mathrm{N}, \mathrm{P}$ and $\mathrm{K}$ ).

Therefore is concluded that there was a yield response in the variety Fianna, by the application of ammonium diphosphate, phosphonitrate and potassium chloride; and such response was associated with optimal doses for unlimited and limited capital in the locality La Peñuela, State of Mexico for Andosol soil.

\section{End of the English version}

Holford, I. C. R. 1997. Soil phosphorus: its measurement and its uptake by plants. Aust. J. Soil Res. 35:227-239.

Hong, Li.; León, L.; Parent, L. E. and Karma, A. 2006. Simulation modeling of soil land plant nitrogen use in a potato cropping system in the humid and cool environment Elsevier. Agric. Ecosys. Environ. 115:248-260.

Oltra, C. M. A.; Mangas, V. J.; Garmendia, I.; Llopis, A. y Martínez, J. 2002. La nutrición mineral de la papa. El cultivo de la papa. Editoral Mundi Prensa. 81 p.

Rubio, C. O.A.; Rangel, G. I. A.; Flores, L. R.; Magallanes, G. J. V.; Díaz, H. C.; Zavala, Q. T. E.; Rivera, P. A.; Cadena, H. M.; Rocha, R. R.; Ortiz, T. C.; López, D. H.; Díaz, V. M. y Paredes, T.A. 2000. Manual para la producción de papa en las sierras y valles altos del centro de México. Instituto Nacional de Investigaciones Forestales, Agrícolas y Pecuarias (INIFAP). Centro de Investigación Regional del Centro (CIRCE). Secretaría de Agricultura Ganadería y Desarrollo Rural (SAGARPA). Libro técnico Núm. 1. División Agrícola. 67 p.

Rueda, R.; Romero, G.; Saldaña, A. y Vázquez, R. 1991. Producción de papa en función de fertilizante y composta en Puebla, México. Simposium Núm. 14. Departamento de Investigación en Ciencias Agrícolas del Instituto de Ciencias de la Benemérita Universidad de Puebla. Puebla, México. 5 p.

Secretaría de Economía (SE). 2002. Norma Oficial de la papa: NMXFF-022-SCFI-2002.http://www.conpapa.org.mx/pdfs/norma de calidad de papa.doc. (consultado marzo, 2010).

Sifuentes, I. E.; Macias, C. J.; Flores, G. H. y Gómez, A. H. 2009. Demandas nutrimentales del cultivo de papa (Solanum tubereosum L.) y su importancia en el manejo de la fertilización. In: XIII Congreso nacional de papa. Tlapa, Jalisco. 52-55 pp. 
Syers, J. K.; Jhonston, A. E. and Curtins, D. 2008. Efficiency of soil and fertilizer phosphorus use. FAO. Fertilizer and Plant Nutrition Bulletin 18. Rome Italy. 108p.

Turrent, F. A. 1981. El Método grafico-estadístico para la interpretación económica de experimentos conducidos con la matriz Plan Puebla I. Agrociencia. 46:17-42.
Universidad Autónoma del Estado de México (UAEM). 2009. Centro de Investigación y Estudios Avanzados. Laboratorio de Suelos. Análisis físico y químico de muestra de suelos. 1-2 pp.

Volke, H. V. 1982. Optimización de insumos de la producción en la agricultura, Centro de Edafología, Colegio de Postgraduados en Ciencias Agrícolas. México. 61 p. 